\title{
How enterprise strategies are related to innovation and productivity change: An empirical study of Japanese manufacturing firms
}

Hidemichi Fujii ${ }^{1}$, Kazuma Edamura², Koichi Sumikura², Yoko Furusawa ${ }^{2}$, Naomi Fukuzawa², Shunsuke Managi ${ }^{2,3^{*}}$

${ }^{1}$ Graduate School of Fisheries Science and Environmental Studies, Nagasaki University 1-14 Bunkyo-machi, Nagasaki 852-8521, Japan

${ }^{2}$ National Institute of Science and Technology Policy, Project Office C405, National Graduate Institute for Policy Studies, 7-22-1, Roppongi, Minato-ku, Tokyo 106-8677, Japan

${ }^{3}$ Graduate School of Environmental Studies, Tohoku University, 6-6-20 Aramaki-Aza Aoba, Aoba-Ku, Sendai 980-8579, Japan (* Corresponding author, managi.s@gmail.com)

\begin{abstract}
This study analyzes the total factor productivity of 1,067 Japanese manufacturing firms. In production estimation, we employ the directional distance function and Luenberger productivity indicator. Research and development strategy survey data are used to analyze the determinant factors related to improvements in innovation and productivity. Our results indicate that increasing technology and knowledge through a "black box" process is related to an increase in productivity. Furthermore, the protection and management of production knowledge and expertise is a valid method of increasing global technical change.
\end{abstract}

Keywords: Innovation, productivity change, $R \& D$ strategy, directional distance function, Japanese manufacturing firms

JEL Classification: D24, J24, O47, O38 


\section{Introduction}

Technical innovation is a key factor for a company to gain an advantage in a competitive market because innovators that release products or services to markets earlier than their competitors can gain a leading market position and be the first to establish customer relationships. This advantage can prevent competitors from occupying a significant portion of the market in the future, further maximizing innovator profit. The development of optional goods, articles of consumption, and after-sales services can contribute to innovator profit. Competitive firms in the market are expected to pay income tax and generate employment because they turn a profit. Thus, establishing an innovation support system is important to increase the number of market-competitive companies that contribute to economic development.

There are many existing studies that have analyzed the determinant factors of innovation. Those studies have typically considered the influence of research and development (R\&D) expenditures, internationalization, mergers, ownership, the number of patents, and spillovers to total factor productivity (TFP) ${ }^{1}$. Whereas most previous studies use quantitative data to find determinants of innovation, we consider quantitative data that cannot easily be used to represent corporate strategy because companies often do not open their knowledge to the public. Rather, they keep this information a secret as a "black box" ${ }^{2}$. Therefore, a comprehensive corporate strategy dataset is needed to understand the determinants of innovation, one which includes black-box factors.

There are several previous studies analyzing how a black-box strategy contributes to TFP improvement and increases the level of innovation. However, most focus on U.S. manufacturing companies. ${ }^{3}$ There is no empirical analysis study about Japanese manufacturing firms. According to Daly (1998) and Fujii et al. (2010), Japan and the U.S. have different entrepreneurship and business cultures. Additionally, Japanese manufacturing firms have developed their own R\&D culture and strategies. ${ }^{4}$ For these reasons, we believe the research about R\&D strategy, including black-box strategies, considering Japanese manufacturing firms is important.

\footnotetext{
${ }^{1}$ Determining factors of innovation have been analyzed in many countries, including the U.S. (Chun and Nadiri 2008), Italia (Bronzini and Piselli 2009; Antonelli and Scellato 2013), Portugal (Teixeira and Fortuna 2010), Canada (Souare 2013), France (Duguet 2006), Korea (Jung and Lee 2010), Spain (Manez et.al. 2013), Netherlands (Den Butter, Mohlmann, and Wit 2008), and Japan (Fujii, Managi, and Kawahara 2011; Tanaka and Managi, 2013).

2 The protection of a newly implemented innovation by a patent provides exclusive rights to innovators and prevents others from using the same innovation. Such exclusive rights can also be obtained from the protection of a design patent and/or trademark. The time period of patent protection is limited, whereas protection by trade secrets has an unlimited time period unless another organization implements the same innovation independently. If the design or architecture of a product or service is complex, then competitors are unable to replicate a similar innovation, even if the product or service is without patent protection. If the fundamental technology or production process is unknown (i.e., a black box), then competitors are prevented from implementing a similar innovation.

${ }^{3}$ Koufteros, Cheng, and Lai (2007) used 157 U.S. manufacturing firms' data, Venturini (2012) analyzed 12 U.S. manufacturing industries' data, and Zhao, Cavusgil, and Cavusgil (2014) focused on 136 U.S. high-tech firms.

${ }^{4}$ A representative example is the Kanban system developed by Toyota (Lage-Junior and Godinho-Filho 2010).
} 
In this study, our objective is to clarify the determinants and strategic management factors related to innovation and productivity change. This study utilizes unique data with respect to the different R\&D strategies of Japanese corporations. We analyze data from 1,067 Japanese firms and estimate the innovation indicator using a directional distance function (DDF) model. This study contributes to the existing literature in two key ways: (1) by analyzing both global technical change (GTC) and local technical change (LTC) indicators whose determinants have not been previously analyzed and (2) by being the first empirical study of Japanese manufacturing companies to focus on the effect of a blackbox strategy on productivity change and innovation.

The remainder of the paper is organized as follows. Chapter 2 describes our methodology. Chapter 3 presents the data used in the study. The results of the TFP change are discussed in Chapter 4. Chapter 5 concludes the paper.

\section{Methodology}

\subsection{Productive inefficiency evaluation under convex and non-convex assumptions}

There is significant debate surrounding the shape of the production function that should be analyzed (Kerstens and Managi 2012). The choice between non-convexity and convexity in measuring TFP change relates to the nature of technological progress. One non-convex specification of production technology (NCP) is the non-convex Free Disposable Hull model (introduced by Deprins, Simar, and Tulkens 1984). The NCP model has the advantage of eventually allowing for local rather than GTC (see, e.g., the discussion in Tulkens 1993). Although this distinction between LTC and GTC plays a role in some theoretical work (e.g., Atkinson and Stiglitz 1969), only a few studies have analyzed this issue empirically (e.g., Kerstens and Managi 2012).

Figure 1 presents a graphic of GTC and LTC. Figure 1 presents the performance of six firms for years $t$ and $t+1$. Here, we consider two cases. The first case is that all six firms shift in the upper left direction, which displays more efficient production (less input, more output). This frontier line shift represents GTC. The second case is that only firm D shifts in the upper left direction in year $t+1$, and the other firms stay at the same point they were at in year t. In this case, the frontier line shape is changed partially from year $t$ to $t+1$. This partial frontier line shift is called LTC.

$<$ Figure 1. Global technical change and local technical change $>$

We measure productivity change by examining relative productivity among Japanese manufacturing firms using a DDF. One advantage of DDF is their applicability to both convex and nonconvex specification. Another point is their applicability to the measurement of a productivity change indicator. The convex specification of the production technology (CP) formulation calculating the distance function for firm $k$ can be computed using the following optimization problem: 


$$
\mathrm{D}_{c p}\left(x_{k}^{n}, y_{k}^{m}\right)=\text { Maximize } \beta_{k}^{c p}
$$

subject to

$$
\begin{aligned}
& \sum_{j}^{J} \lambda_{j} y_{j}^{m} \geq\left(1+\beta_{k}^{c p}\right) y_{k}^{m} \quad m=1, \cdots, M \\
& \sum_{j}^{J} \lambda_{j} x_{j}^{n} \leq\left(1-\beta_{k}^{c p}\right) x_{k}^{n} \quad n=1, \cdots, N \\
& \sum_{j}^{J} \lambda_{j}=1 \\
& \lambda_{j} \geq 0 \quad j=1, \cdots, J
\end{aligned}
$$

where $m$ is the output, $n$ is the input, $j$ is the firm, and $\lambda_{j}$ is the weight variable. Similarly, our NCP formulation calculates the distance function by solving the following optimization problem:

$$
\mathrm{D}_{n c p}\left(x_{k}^{n}, y_{k}^{m}\right)=\text { Maximize } \beta_{k}^{n c p}
$$

subject to

$$
\begin{aligned}
& \sum_{j}^{J} \lambda_{j} y_{j}^{m} \geq\left(1+\beta_{k}^{n c p}\right) y_{k}^{m} \quad m=1, \cdots, M \\
& \sum_{j}^{J} \lambda_{j} x_{j}^{n} \leq\left(1-\beta_{k}^{n c p}\right) x_{k}^{n} \quad n=1, \cdots, N \\
& \sum_{j}^{J} \lambda_{j}=1 \\
& \lambda_{j} \in\{0,1\} \quad \forall j \\
& \lambda_{j} \geq 0 \quad j=1, \cdots, J
\end{aligned}
$$

This algorithm highlights a difference between convex and non-convex methodologies. Figure 2 compares the production frontier line shape between non-convex and convex technology. The role of the integrality constraint is particularly important to recognize a relationship of dominance between observed products. An observation may be declared efficient and may be considered part of the boundary of the reference technology if it is un-dominated. However, in other cases, an observation may be declared inefficient (i.e., it lies in the interior of the technology) if it is dominated by at least one other observation. In the latter case, the mixed integer program identifies a dominating observation that serves as a reference because it corresponds to the maximum of the computed efficiency measure.

$<$ Figure 2. Production frontier line under non-convex and convex technologies $>$ 
In contrast, the programs that are used in the convex case compute the distance to the frontier of a convex envelope of the data. Although dominance also plays a role in identifying this envelope, the additional requirement of convexity introduces the possibility that un-dominated observations can be inefficient because they do not lie in the convex envelope of the data.

Empirical studies that have employed the distance function model have typically assumed either constant returns to scale (CRS) or variable returns to scale (VRS). In this study, we assume that VRS capture the firm scale effect.

\subsection{Luenberger Productivity Indicator}

The TFP is computed with the results of the distance function model and is derived as follows (Chambers, Chung, and Färe 1998):

$$
\begin{aligned}
& \text { TFP }_{t}^{t+1}=\text { TECHCH }_{t}^{t+1}+\text { EFFCH }_{t}^{t+1} \\
& \text { TECHCH }_{t}^{t+1}=\frac{1}{2}\left\{\vec{D}^{t+1}\left(x_{t}, y_{t}\right)+\vec{D}^{t+1}\left(x_{t+1}, y_{t+1}\right)-\vec{D}^{t}\left(x_{t}, y_{t}\right)-\vec{D}^{t}\left(x_{t+1}, y_{t+1}\right)\right\} \\
& \operatorname{EFFCH}_{t}^{t+1}=\vec{D}^{t}\left(x_{t}, y_{t}\right)-\vec{D}^{t+1}\left(x_{t+1}, y_{t+1}\right)
\end{aligned}
$$

where $x_{t}$ is the input for year $t, x_{t+1}$ is the input for year $t+1, y_{t}$ is the desired output for year $t$, and $y_{t+1}$

is the desired output for year $t+1 . \vec{D}^{t}\left(x_{t}, y_{t}\right)$ is the inefficiency score of year $t$ based on the frontier curve in year t. Similarly, $\vec{D}^{t+1}\left(x_{t}, y_{t}\right)$ is the inefficiency score of year $t+1$ based on the frontier curve in year $\mathrm{t}+1$.

The TFP score indicates the productivity change relative to the benchmark year. The TFP includes all types of productivity change, which is divided into technical change (TECHCH) and efficiency change (EFFCH). TECHCH indicates shifts in the production frontier, and EFFCH indicates changes in a production unit's position relative to the frontier (i.e., catching up).

\subsection{Global and local technical change indicators}

Recently, Kerstens and Managi (2012) developed the identification methodology for GTC and LTC using productivity indicators. The notion of GTC and LTC has been widely discussed following its introduction by Atkinson and Stiglitz (1969). The basic premise is that technical change may not require a global shift in production technology but may lead to local change for specific segments of production technology.

CP and NCP models impose flexible VRS assumptions. Furthermore, LTC plays a role in new growth theory. LTC is known to lead to path dependency, local learning, and efficiency dynamics (see, 
e.g., Stiglitz, 1987; Foray, 1997; Antonelli, 2006). LTC explains growth, convergence clubs, and divergence in the real economy (Basu and Weil, 1998) .

First, we define the GTC that results from efficient observations at two time periods that experience positive TC between the years $\mathrm{t}$ and $\mathrm{t}+1$ under the $\mathrm{CP}$ model as

$$
\operatorname{GTC}\left(\left(x_{t}, y_{t}\right)\left(x_{t+1}, y_{t+1}\right)\right)=\left\{D_{c p}^{t}\left(x_{t}, y_{t}\right)=0 \cap D_{c p}^{t+1}\left(x_{t}, y_{t}\right)=0 \cap T E C H C H_{c p}^{t, t+1}>\right.
$$

$0\}$

The arguments of the proportional distance function are suppressed to condense the notation. Next, we define the LTC that results from efficient observations at two time periods in terms of NCP but inefficient in terms of CP and that experiences positive TC in terms of NCP between two time periods as

$\operatorname{LTC}\left(\left(x_{t}, y_{t}\right)\left(x_{t+1}, y_{t+1}\right)\right)=$

$\left\{\left[D_{n c p}^{t}\left(x_{t}, y_{t}\right)=0 \cap D_{c p}^{t}\left(x_{t}, y_{t}\right)>0\right] \cap\left[D_{n c p}^{t+1}\left(x_{t}, y_{t}\right)=0 \cap D_{c p}^{t+1}\left(x_{t}, y_{t}\right)>0\right] \cap T E C H C H_{n c p}^{t, t+1}>0\right\}(16)$

It is easier to follow the conditions in (16) than to satisfy the conditions in (15). However, it is not possible to abandon the efficiency requirement altogether because otherwise, the global versus local distinction could not be maintained. Both global and local are defined without recourse to a mathematical distance metric.

In Figure 2, firms B, D, and F satisfy Equation (15), and firms C and E satisfy Equation (16). Thus, firms B, D, and F are identified as GTC, and firms $\mathrm{C}$ and $\mathrm{E}$ are identified as LTC from years $\mathrm{t}$ to $\mathrm{t}+1$. Firm A does not achieve GTC or LTC because TECHCH = 0 under the CP and NCP models.

\section{Data}

This study uses two firm-level panel datasets. The first dataset is for productivity estimation ( $1^{\text {st }}$ step of the analysis), and the other is for the determinant analysis of productivity and innovation ( $2^{\text {nd }}$ step of the analysis). Table 1 provides a description of the data by industry for each dataset.

$<$ Table 1. Description of data sample by industry type $>$

The dataset for the $1^{\text {st }}$ step of the analysis includes data for 1,067 firms that were obtained from the "NEEDS" financial database of Nihon Keizai Shimbun Inc. We use four financial data variables: sales, capital stock, labor cost, and material costs. Capital stock, labor cost, and material cost were used 
in the DDF model as inputs, and sales was used as the output. ${ }^{5,6}$ Table 2 presents the average values of the variables for the productivity analysis. All industries saw declined sales from 2008 to 2009 due to the financial crisis called the "Lehman shock". In this period, the demand for products decreased, and manufacturing firms could not maintain their facility operation rates. However, all industries increased sales from 2009 to 2010, especially medical product and precision products, except the miscellaneous industry..

$<$ Table 2. Average value of data variables for the productivity analysis $>$

The firms that are used in this analysis are listed in the Tokyo Stock Exchange and represent 16 manufacturing sectors. Using the dataset for the $1^{\text {st }}$ step of the analysis, we calculate the GTC, LTC, and TFP change by type of industry separately because the shape of the production frontier line is different among the different industry types.

The second dataset is survey data about the firms' R\&D strategies. We use the Survey on Research Activities of Private Corporations in Japan by the National Institute of Science and Technology Policy (NISTEP), Ministry of Education, Culture, Sports, Science and Technology (MEXT). The survey focuses on R\&D strategies to gain market competitiveness, including the "black-box" strategy of keeping firm knowledge secret. Thus, we believe that these R\&D strategy survey data are unique, and our study is the first to apply this dataset to analyze determinant of productivity change and innovation.

We use two years of survey data, fiscal years 2010 and 2011. The fiscal year 2010 survey evaluates corporate R\&D strategy in 2009. The survey was conducted from January to February in 2011, and 1,268 out of 3,546 firms responded to the survey (the response rate was 35.7\%). The fiscal year 2011 survey evaluates corporate R\&D strategy in 2010. That survey was conducted from February to March in 2012, and 1,263 out of 3,380 firms responded (the response rate was $37.4 \%)^{7}$. The survey was conducted among private corporations that have capital stock of at least 100 million yen and that conduct R\&D activities. The survey developers were careful not to produce sample bias in the data.

The R\&D strategy surveys focus on the importance of strategy to gain profit from newly developed products and services. Recognition of importance was measured using a Likert scale ranging from 1 for "not important" to 5 for "very important ".

\footnotetext{
${ }^{5}$ The estimate of capital stock is calculated using the perpetual inventory method with a benchmark year of 1990 . The capital depletion rate is 8.38\%, as calculated by Hayashi and Inoue (1991).

${ }^{6}$ All financial data variables are deflated in the real price from the year 2000. The nominal equipment investment and sales are made substantive using the GDP deflator of SNA from the Cabinet Office. Moreover, the labor cost (labor and employment costs) is measured by the consumer price index that the Ministry of Internal Affairs and Communications makes public, and the intermediate is provided by the Corporate Goods Price Index from the Bank of Japan.

${ }^{7}$ The survey does not have sample bias between responding and non-responding firms. There is no statistically significant difference in sales per capita and R\&D expenditures per capita between them. Please refer to the appendix for more details.
} 
The majority of survey questions are limited to the main category of business (the business field with the largest sales volume) to avoid the co-existence of data from various business categories from enterprise diversification. Therefore, the analytical objective in this study is limited to activity in the main category of business for each firm.

We combine two datasets, the financial dataset for production analysis and the R\&D strategy survey dataset. We found 352 firms whose data are available to use from both datasets. Thus, we use 352 firms' data for the $2^{\text {nd }}$ step of the analysis. Table 3 presents the 352 firms' average values for the data variables used in the determinants analysis. Table 3 illustrates that "protection by patent" is the highest value of all strategies. This result implies the manufacturing firms recognize that a patent is important to gain profit from newly developed products and services. In contrast, "complication of product architecture and service design" is the only strategy scoring less than 3.00. Thus, manufacturing firms do not focus on this strategy often.

$<$ Table 3. Average value of data variables for the determinant analysis $>$

\section{Results}

\section{4-1. Results of the productivity analysis}

Tables 4 and 5 present the results of the productivity analysis using a $\mathrm{DDF}^{8}$. Here, we only discuss the TFP, EFFCH, and TECHCH indicators under the CP model because the NCP model does not consider the global technical frontier. Therefore, Japanese manufacturing companies race to acquire profit on the global market but not on a domestic local market. We only use the results from the NCP model to estimate the LTC indicator.

Table 4 presents the results for $\mathrm{TFP}_{\mathrm{CP}}$, $\mathrm{EFFCH}_{\mathrm{CP}}$, and $\mathrm{TECHCH}_{\mathrm{CP}}$ in the two time periods. From Table 4, TFP ${ }_{\mathrm{CP}}$ decreases in all industries between 2008 and 2009, except in the textile industry, and it increased in all industries between 2009 and 2010. Only the textile industry increased TFP in both periods. This result suggests that technical changes occurred in the Japanese textile industry even though financial crisis occurred. One reason for this is that the textile industry quickly adapted the demand decline due to the Lehman shock. As shown in Table 2, the textile industry reduced sales by $21 \%$ between 2008 and 2009 but also reduced labor costs by $17 \%$ and materials costs by $23 \%$.

Moreover, the $\mathrm{EFFCH}_{\mathrm{CP}}$ score was close to zero in both time periods, whereas $\mathrm{TECHCH}_{\mathrm{CP}}$ was negative from 2008 to 2009 and positive from 2009 to 2010. The $\mathrm{EFFCH}_{\mathrm{CP}}$ indicates the difference in efficiency between an efficient firm and inefficient firm. The $\mathrm{TECHCH}_{\mathrm{CP}}$ indicates the change in the production frontier constructed by sets of the most efficient firms, measured by TFP. Fourteen out of

\footnotetext{
8 This study applies the non-parametric deterministic production function approach, which does not consider the measurement error. Thus, we are not able to test the measurement error. This is a limitation of our research.
} 
16 industries had a decrease in TFP due to the decrease in TECHCH$_{\mathrm{CP}}$. This result suggests that productivity in the Japanese manufacturing sector decreased between 2008 and 2009 because the productivity of the manufacturing sector decreased as a whole, not because of decreases in the productivity of individual firms.

This finding suggests that manufacturing productivity increased between 2009 and 2010 not only because individual firm productivity increased but also because the productivity of the manufacturing sector as a whole benefitted from technological progress. One interpretation of this result is a rebound effect one year after the Lehman shock.

$<$ Table 4. Productivity change scores $>$

Table 5 indicates that a large share of firms in the textile industry and precision products industry achieved GTC and LTC from 2008 to 2009. In later periods, there are 13 industries with an increase in the number of firms that achieved LTC and 15 industries (with the exception of precision products) with an increase in the number of firms that achieved GTC relative to the results observed for the 20082009 period.

Moreover, the number of firms that achieved GTC increased despite the Lehman shock, especially the coal, oil, and rubber industries. This finding suggests that the production frontier line shifted in a more efficient direction from 2009 to 2010. The share of firms that achieved LTC is higher in the medical products, nonferrous metal, and transport equipment industries than in other industries. This result suggests that these industries achieved a partial production frontier line shift and that several firms did not achieve technical change.

$<$ Table 5. Result of the global and local technical change analysis >

\section{4-2. Strategies for influencing TFP change and innovation}

This study used random-effects generalized least squares (GLS) regression to estimate the determinants of TFP ${ }_{\mathrm{CP}}$ change. We select this model because the dataset for the $2^{\text {nd }}$ step includes two years of panel data. ${ }^{9}$ Additionally, we applied random-effects logistic regression to analyze the determinants of GTC and LTC because GTC and LTC are binary data, and the dataset includes two years of panel data. The dependent variables, shown in Table 6, are TFP, GTC, and LTC. Table 6 presents the results using enterprise recognition of importance as the independent variable. Recognition of the importance of a strategy was measured by a Likert scale ranging from 1 for "not important" to 5 for "very important".

\footnotetext{
${ }^{9}$ We selected random effects specifications based on Hausman test results.
} 
Table 6 demonstrates that the "making the black box" variable has a positive effect on TFP ${ }_{\mathrm{CP}}$ change at the 10 percent significance level. This result implies that Japanese manufacturing firms that employed the black-box strategy between 2008 and 2010 tended to increase TFP ${ }_{C P}$ more than firms that did not. Previous studies have found evidence that the black-box strategy contributes to TFP improvement and increases innovation in the U.S. manufacturing sector. However, there is no empirical analysis using Japanese manufacturing firms. We believe this is the first empirical evidence that the black-box strategy contributes to TFP improvement using Japanese manufacturing firm data.

Meanwhile, the "cost advantage by scale merit" and "flexible production system" variables have a negative effect on $\mathrm{TFP}_{\mathrm{CP}}$. Furthermore, the productivity change is lower for enterprises that value the achievement of scale merit.

Next, we analyzed the factors that influence the achievement of GTC and LTC. Table 6 illustrates that placing importance on the "protection and management of production knowledge" has the effect of increasing the achievement of GTC. This finding suggests that the frontier undergoes a positive shift through the protection and management of production expertise. However, this analysis also reveals a lower rate of GTC achievement by enterprises that valued the "construction of flexible production systems for demand change”.

Two strategic factors influence the achievement of LTC: the "standardization of products/services" and the "establishment of relationships with customers through early commercialization". Because approaches to standardization are associated with promoting the achievement of LTC by enterprises, the accomplishment rate of LTC by enterprises that value this factor is higher than for other enterprises. The achievement of LTC may be promoted because achievement in the direction of standardization yields incremental technological progress. Meanwhile, the LTC achievement levels for firms who prioritize the "establishment of relationships with customers through early commercialization" tend to be lower than for firms who do not prioritize this variable.

These results demonstrate that the strategies used to achieve positive TFP growth are not same as those used to achieve GTC or LTC. The results for the strategy of "protection and management of production knowledge" suggest that the management environment is valid as a method of increasing TFP $_{\mathrm{CP}}$ for those firms with specific characteristics and positive shifts in the technological frontier. However, standardization is not a valid method for dramatically increasing TFP ${ }_{\mathrm{CP}}$. Nevertheless, the effect accumulates so incrementally that standardization may induce incremental innovation.

$<$ Table 6. Result of the determinant factors of productivity change and innovation>

\section{Conclusions}

This study examined the relationship between innovation and productivity using R\&D activity data from Japanese corporations. We estimate productivity change and technical change indicators 
using the DDF. Additionally, determinant analysis was applied to analyze which strategic management factors are associated with improvements in productivity and innovation.

The results indicate that TFP declined from 2008 to 2009 in nearly all industries, likely due to the Lehman shock of September 2008. In contrast, during 2009 and 2010, an increase in TFP was found in nearly all industries, implying that the productivity of the Japanese manufacturing sector increased between 2009 and 2010.

We then analyzed the relationship between the corporate strategies for obtaining profit from innovation and productivity. Firms that valued "making a black box of knowledge and technology" were found to achieve productivity improvement. However, firms that value "cost advantages through the achievement of scale merit" or "construction of flexible productivity system for demand change" were found to decrease productivity from 2008 to 2010.

Studying the corporate strategies that influence the achievement of technical change, we found that the "protection and management of production expertise" had increased the rate of achieving GTC. Firms that valued the "construction of flexible production systems to respond to changes in demand" exhibited a lower GTC achievement rate. The results pertaining to the protection and management of production expertise suggest that the management environment is valid as a method of increasing TFP for those firms with specific characteristics and positive shifts in the technological frontier.

It is important for policymakers and corporate decision makers to understand the determinants of productivity and technical innovation. Our results demonstrate that keeping firm knowledge in a "black box" contributes to productivity growth. In general, the government requires the disclosure for the outcome of corporate $R \& D$ activities if firms accept a subsidy. We suggest creating a $R \& D$ scheme that allows for a black box of knowledge and technology as an effective way to improve productivity.

Further research should investigate the differences between the agriculture industry and service sectors in addition to manufacturing sectors. Such an analysis could clarify this causal relationship between productivity and R\&D strategy in relation to industrial characteristics. Based on individual causal relationships, we can foster the effective economic development policies that each firm needs to achieve technical development. 


\section{References}

Antonelli, C. 2006. "Path dependence, localized technological change and the quest for dynamic efficiency." In New Frontiers in the Economics of Innovation and New Technology. Essays in Honor of Paul David, edited by Antonelli, C., D. Foray, B. Hall, and E. Stenmueller, 51-69. Cheltenham and Northampton, MA: Elgar.

Antonelli, C., and G. Scellato. 2013. "Complexity and technological change: knowledge interactions and firm level total factor productivity.” Journal of Evolutionary Economics 23: 77-96.

Atkinson, A. B., and J. E. Stiglitz. 1969. “A new view of technological change.” Economic Journal 79 (315): 573-578.

Basu, S., and D. N. Weil. 1998. “Appropriate technology and growth.” Quarterly Journal of Economics 113 (4): 1025-1054.

Bronzini, P., and P. Piselli. 2009. "Determinants of long-run regional productivity with geographical spillovers: The role of R\&D, human capital and public infrastructure.” Regional Science and Urban Economics 39: 187-199.

Chambers, R. G., Y. Chung, and R. Färe. 1998. "Profit, directional distance functions, and Nerlovian efficiency.” Journal of Optimization Theory and Applications 98 (2): 351-364.

Chun, H., and M. Nadiri. 2008. “Decomposing productivity growth in the U.S. computer industry.” The Review of Economics and Statistics 90 (1): 174-180.

Daly, G. G. 1998. “Entrepreneurship and business culture in Japan and the U.S.” Japan and the World Economy 10: 487-494.

Den Butter, F., J. Mohlmann, and P. Wit. 2008. "Trade and product innovations as sources for productivity increases: an empirical analysis.” Journal of Productivity Analysis 30(3): 201-211.

Deprins, D., D. Simar, and H. Tulkens. 1984 “Measuring Labor Efficiency in Post Offices.” In The Performance of Public Enterprises: Concepts and Measurements, edited by Marchand, M., P. Pestieau, and H. Tulkens, North Holland, Amsterdam.

Duguet, E. 2006. “Innovation height, spillovers and tfp growth at the firm level: Evidence from French manufacturing.” Economics of Innovation and New Technology 15 (4): 415-442.

Foray, D. 1997. "The dynamic implications of increasing returns: Technological change and path dependent inefficiency.” International Journal of Industrial Organization 15 (6): 733-752.

Fujii, H., T. Kimbara, S. Kaneko, and D. Gibson. 2010. "Mechanism of corporate environmental management: Empirical study for U.S. and Japanese Companies.” In Energy and Innovation: 
Structural Change and Policy Implications, edited by van Geenhuizen, M., W. Nuttall, D. Gibson, and E. Oftedal, 343-368, Purdue University Press.

Fujii, H., S. Managi, and H. Kawahara. 2011. "The Pollution Release and Transfer Register system in the U.S. and Japan: An analysis of productivity.” Journal of Cleaner Production 19 (12): 13301338.

Hayashi, F., and T. Inoue. 1991. "The Relation between Firm Growth and Q with Multiple Capital Goods: Theory and Evidence from Panel Data on Japanese Firms." Econometrica 59(3): 731-53.

Jung, M., and K. Lee. 2010. "Sectoral systems of innovation and productivity catch up: determinants of the productivity gap between Korean and Japanese firms.” Industrial and Corporate Change 19 (4): 1037-1069.

Kerstens., K., and S. Managi. 2012. “Total factor productivity growth and convergence in the petroleum industry: Empirical analysis testing for convexity." International Journal of Production Economics 139 (1): 196-206.

Koufteros, X. A., T. C. E. Cheng, and K. H. Lai. 2007. ““Black-box” and "gray-box” supplier integration in product development: Antecedents, consequences and the moderating role of firm size.” Journal of Operations Management 25: 847-870.

Lage-Junior, M., and M. Godinho-Filho. 2010. "Variations of the Kanban system: Literature review and classification.” International Journal of Production Economics 125: 13-21.

Manez, J., M. Rochina-Barrachina, A. Sanchis, and J. A. Sanchis. 2013. "Do process innovation boost SMEs productivity growth?” Empirical Economics 44 (3): 1373-1405.

Souare, M. 2013. "Productivity growth, trade and FDI nexus: evidence from the Canadian manufacturing sector.” Journal of Technology Transfer 38 (5): 675-698.

Stiglitz, J.E. 1987. “Learning to learn, localized learning and technological progress.” In Economic Policy and Technological Performance, edited by McGuire, C.B., and P. Stoneman, 125-153, Cambridge University Press, Cambridge.

Tanaka, K., and S. Managi. 2013. “Measuring Productivity Gains from Deregulation of the Japanese Urban Gas Industry.” Energy Journal 34(4): 181-198.

Teixerira, A., and N. Fortuna. 2010. "Human capital, R\&D, trade, and log-run productivity. Testing the technological absorption hypothesis for the Portuguese economy, 1960-2001.” Research Policy 39: 335-350.

Tulkens, T. 1993. "On FDH Efficiency Analysis: Some Methodological Issues and Applications to Retail Banking, Courts, and Urban Transit.” The Journal of Productivity Analysis 4: 183-210. 
Venturini, F. 2012. "Looking into the black box of Schumpeterian growth theories: An empirical assessment of R\&D races.” European Economic Review 56: 1530-1545.

Zhao, Y., E. Cavusgil, and S. T. Cavusgil. 2014. "An investigation of the black-box supplier integration in new product development.” Journal of Business Research 67: 1058-1064. 
Table 1. Description of data sample by industry type

\begin{tabular}{|c|c|c|c|c|}
\hline \multirow[b]{2}{*}{ Industry name } & \multicolumn{2}{|c|}{ Data for productivity analysis } & \multicolumn{2}{|c|}{ Data for determinants analysis } \\
\hline & \# of sample & Share & \# of sample & Share \\
\hline Food and beverage & 85 & $8 \%$ & 25 & $7 \%$ \\
\hline Textile & 37 & $3 \%$ & 12 & $3 \%$ \\
\hline Pulp and paper & 15 & $1 \%$ & 5 & $1 \%$ \\
\hline Chemical product & 159 & $15 \%$ & 57 & $16 \%$ \\
\hline Medical product & 38 & $4 \%$ & 16 & $5 \%$ \\
\hline Coal and oil & 9 & $1 \%$ & 5 & $1 \%$ \\
\hline Rubber & 16 & $1 \%$ & 5 & $1 \%$ \\
\hline Nonferrous & 27 & $3 \%$ & 10 & $3 \%$ \\
\hline Iron and steel & 46 & $4 \%$ & 21 & $6 \%$ \\
\hline Metal & 57 & $5 \%$ & 12 & $3 \%$ \\
\hline Ceramic & 48 & $4 \%$ & 13 & $4 \%$ \\
\hline Machine & 170 & $16 \%$ & 49 & $14 \%$ \\
\hline Electric product & 181 & $17 \%$ & 68 & $19 \%$ \\
\hline Transportation equipment & 90 & $8 \%$ & 35 & $10 \%$ \\
\hline Precision products & 29 & $3 \%$ & 5 & $1 \%$ \\
\hline Miscellaneous & 60 & $6 \%$ & 14 & $4 \%$ \\
\hline Total & 1067 & $100 \%$ & 352 & $100 \%$ \\
\hline
\end{tabular}

Table 2. Average value of data variables for the productivity analysis

\begin{tabular}{|c|c|c|c|c|c|c|c|c|c|c|c|c|}
\hline \multirow[b]{2}{*}{ Industry name } & \multicolumn{3}{|c|}{ Sales } & \multicolumn{3}{|c|}{ Capital stock } & \multicolumn{3}{|c|}{ Labor cost } & \multicolumn{3}{|c|}{ Material cost } \\
\hline & 2008 & 2009 & 2010 & $\begin{array}{r}200 \\
8 \\
\end{array}$ & $\begin{array}{r}200 \\
9 \\
\end{array}$ & $\begin{array}{r}201 \\
0 \\
\end{array}$ & $\begin{array}{r}200 \\
8 \\
\end{array}$ & $\begin{array}{r}200 \\
9 \\
\end{array}$ & $\begin{array}{r}201 \\
0 \\
\end{array}$ & $\begin{array}{r}200 \\
8 \\
\end{array}$ & $\begin{array}{r}200 \\
9 \\
\end{array}$ & $\begin{array}{r}201 \\
0 \\
\end{array}$ \\
\hline Food and beverage & 139.8 & 125.0 & 127.7 & 41.4 & 42.9 & 42.7 & $\begin{array}{r}10 . \\
1\end{array}$ & $\begin{array}{r}10 . \\
5\end{array}$ & $\begin{array}{r}10 . \\
5\end{array}$ & 31.8 & 29.9 & 29.6 \\
\hline Textile & 53.7 & 42.4 & 48.2 & 32.2 & 31.3 & 30.4 & 7.7 & 6.4 & 6.4 & 14.5 & 11.2 & 12.4 \\
\hline Pulp and paper & 138.8 & 105.4 & 111.0 & $\begin{array}{r}103 . \\
2\end{array}$ & 99.1 & 95.0 & $\begin{array}{r}11 . \\
3\end{array}$ & $\begin{array}{r}11 . \\
2\end{array}$ & $\begin{array}{r}11 . \\
2\end{array}$ & 51.7 & 40.7 & 42.8 \\
\hline Chemical product & 105.6 & 87.2 & 99.6 & 50.0 & 50.4 & 50.7 & 7.8 & 7.6 & 7.7 & 29.9 & 26.6 & 29.9 \\
\hline Medical product & 140.3 & 133.5 & 144.4 & 41.7 & 44.6 & 49.2 & $\begin{array}{r}13 . \\
7\end{array}$ & $\begin{array}{r}13 . \\
0\end{array}$ & $\begin{array}{r}13 . \\
3\end{array}$ & 8.4 & 8.7 & 8.7 \\
\hline Coal and oil & $\begin{array}{r}1,412 . \\
6\end{array}$ & $\begin{array}{r}1,177 . \\
1\end{array}$ & $\begin{array}{r}1,214 . \\
9\end{array}$ & $\begin{array}{r}160 . \\
2\end{array}$ & $\begin{array}{r}164 . \\
9\end{array}$ & $\begin{array}{r}160 . \\
8\end{array}$ & $\begin{array}{r}12 . \\
7\end{array}$ & $\begin{array}{r}13 . \\
3\end{array}$ & $\begin{array}{r}13 . \\
3\end{array}$ & $\begin{array}{r}556 . \\
6\end{array}$ & $\begin{array}{r}514 . \\
5\end{array}$ & $\begin{array}{r}512 . \\
1\end{array}$ \\
\hline Rubber & 166.5 & 109.5 & 144.2 & 88.8 & 89.8 & 91.3 & $\begin{array}{r}18 . \\
7\end{array}$ & $\begin{array}{r}17 . \\
8\end{array}$ & $\begin{array}{r}19 . \\
5\end{array}$ & 54.7 & 39.4 & 51.1 \\
\hline Nonferrous & 182.9 & 126.4 & 157.5 & 66.0 & 65.0 & 64.3 & $\begin{array}{r}12 . \\
5\end{array}$ & $\begin{array}{r}11 . \\
8\end{array}$ & $\begin{array}{r}11 . \\
9\end{array}$ & 60.6 & 67.6 & 68.1 \\
\hline Iron and steel & 199.2 & 137.1 & 179.0 & $\begin{array}{r}112 . \\
2\end{array}$ & $\begin{array}{r}118 . \\
4\end{array}$ & $\begin{array}{r}119 . \\
8\end{array}$ & $\begin{array}{r}13 . \\
8\end{array}$ & $\begin{array}{r}12 . \\
8\end{array}$ & $\begin{array}{r}13 . \\
1\end{array}$ & 96.8 & 67.6 & 88.2 \\
\hline Metal & 44.3 & 37.6 & 40.5 & 27.3 & 27.0 & 26.2 & 6.4 & 6.1 & 6.2 & 14.9 & 13.5 & 14.1 \\
\hline Ceramic & 77.5 & 57.9 & 64.3 & 47.9 & 48.2 & 49.0 & 8.3 & 8.0 & 8.3 & 15.4 & 11.5 & 13.1 \\
\hline Machine & 87.6 & 67.6 & 79.5 & 32.8 & 33.4 & 33.7 & $\begin{array}{r}11 . \\
1\end{array}$ & $\begin{array}{r}10 . \\
4\end{array}$ & $\begin{array}{r}10 . \\
7\end{array}$ & 32.4 & 22.5 & 28.4 \\
\hline Electric product & 331.8 & 318.2 & 402.7 & $\begin{array}{r}101 . \\
1\end{array}$ & 98.6 & 99.5 & $\begin{array}{r}23 . \\
8\end{array}$ & $\begin{array}{r}22 . \\
5\end{array}$ & $\begin{array}{r}23 . \\
0\end{array}$ & 85.6 & 74.7 & 87.5 \\
\hline $\begin{array}{l}\text { Transportation } \\
\text { equipment }\end{array}$ & 506.0 & 427.1 & 471.6 & $\begin{array}{r}166 . \\
6\end{array}$ & $\begin{array}{r}163 . \\
7\end{array}$ & $\begin{array}{r}160 . \\
7\end{array}$ & $\begin{array}{r}43 . \\
6\end{array}$ & $\begin{array}{r}40 . \\
7\end{array}$ & $\begin{array}{r}42 . \\
3\end{array}$ & $\begin{array}{r}280 . \\
4\end{array}$ & $\begin{array}{r}241 . \\
0\end{array}$ & $\begin{array}{r}259 . \\
7\end{array}$ \\
\hline Precision products & 79.6 & 69.8 & 79.7 & 29.2 & 29.8 & 30.7 & $\begin{array}{r}10 . \\
4\end{array}$ & $\begin{array}{r}10 . \\
0\end{array}$ & $\begin{array}{r}10 . \\
9\end{array}$ & 16.8 & 14.9 & 16.1 \\
\hline
\end{tabular}


Miscellaneous

116.3

$90.7 \quad 88.8$

$38.8 \quad 39.2 \quad 39.3$

$\begin{array}{lll}9.7 & 9.0 \quad 9.2\end{array}$

$31.1 \quad 26.5 \quad 22.6$

Note: The units of all variable are billion Japanese yen. All variables are deflated 2000 year price. 
Table 3. Average value of data variables for the determinant analysis

\begin{tabular}{|c|c|c|c|c|}
\hline \multirow{2}{*}{$\begin{array}{l}\text { Question: Is it important business strategy for your company to } \\
\text { gain the profit from new developed product and service? }\end{array}$} & \multicolumn{2}{|c|}{ fiscal year 2010} & \multicolumn{2}{|c|}{ fiscal year 2011} \\
\hline & Mean & st.dev & Mean & st.dev \\
\hline Protection by patent & 4.198 & 0.974 & 4.243 & 0.923 \\
\hline Protection by design patent and trademark & 3.733 & 1.104 & 3.831 & 0.985 \\
\hline protection by trade secret & 3.656 & 0.954 & 3.641 & 0.850 \\
\hline Complication of product architecture and service design & 2.922 & 0.887 & 2.926 & 0.903 \\
\hline Making the "Black Box" (technology and/or process) & 3.423 & 1.021 & 3.517 & 0.974 \\
\hline Differentiation by external design and sensibility element & 3.046 & 1.082 & 3.009 & 1.122 \\
\hline Improvement of convenience by product interface & 3.421 & 1.003 & 3.456 & 0.921 \\
\hline Protection and management of production know-how & 3.852 & 0.892 & 3.880 & 0.824 \\
\hline Internal production of manufacturing device and equipment & 3.293 & 1.003 & 3.364 & 0.977 \\
\hline Cost advantages by achievement of scale merit & 3.164 & 1.019 & 3.144 & 1.032 \\
\hline Cost reduction by early entry into market to create know-how & 3.434 & 0.938 & 3.403 & 0.928 \\
\hline Acquisition of market share by early product/service launch & 3.719 & 0.914 & 3.738 & 0.910 \\
\hline Relationship with customer by early commercialization & 3.791 & 0.931 & 3.797 & 0.894 \\
\hline Development of optional goods and customer services & 3.313 & 0.974 & 3.307 & 0.930 \\
\hline Standardization of product/service & 3.250 & 0.964 & 3.274 & 0.899 \\
\hline Establishment and use of brand (corporate and /or product, service) & 3.798 & 0.938 & 3.800 & 0.852 \\
\hline Construction of flexible productive system for demand change & 3.682 & 0.836 & 3.593 & 0.822 \\
\hline Maintenance of network for sales and service & 3.613 & 0.913 & 3.589 & 0.862 \\
\hline
\end{tabular}

Note: All variables are standardized by five point Likert scale ranging from 1 for "not important" to 5 for "very important".

Table 4. Productivity change scores

\begin{tabular}{|c|c|c|c|c|c|c|}
\hline \multirow[b]{2}{*}{ Industry type } & \multicolumn{3}{|c|}{ From year 2008 to year 2009} & \multicolumn{3}{|c|}{ From year 2009 to year 2010} \\
\hline & $\mathrm{TFP}_{\mathrm{CP}}$ & $\mathrm{EFFCH}_{\mathrm{CP}}$ & TECHCH $_{\mathrm{CP}}$ & $\mathrm{TFP}_{\mathrm{CP}}$ & $\mathrm{EFFCH}_{\mathrm{CP}}$ & $\mathrm{TECHCH}_{\mathrm{CP}}$ \\
\hline Food and beverage & -0.053 & -0.002 & -0.051 & 0.016 & -0.014 & 0.030 \\
\hline Textile & 0.020 & -0.006 & 0.025 & 0.132 & 0.008 & 0.125 \\
\hline Pulp and paper & -0.102 & -0.002 & -0.100 & 0.010 & 0.001 & 0.009 \\
\hline Chemical product & -0.072 & -0.004 & -0.068 & 0.048 & -0.005 & 0.053 \\
\hline Medical product & -0.047 & 0.014 & -0.061 & 0.103 & 0.024 & 0.078 \\
\hline Coal and oil & -0.125 & 0.006 & -0.130 & 0.033 & -0.004 & 0.037 \\
\hline Rubber & -0.135 & -0.003 & -0.133 & 0.092 & 0.012 & 0.081 \\
\hline Nonferrous & -0.161 & 0.001 & -0.163 & 0.104 & -0.020 & 0.124 \\
\hline Iron and steel & -0.111 & 0.034 & -0.146 & 0.076 & -0.017 & 0.094 \\
\hline Metal & -0.034 & 0.007 & -0.041 & 0.015 & 0.017 & -0.002 \\
\hline Ceramic & -0.093 & 0.015 & -0.108 & 0.052 & -0.008 & 0.060 \\
\hline Machine & -0.072 & -0.079 & 0.007 & 0.026 & -0.115 & 0.141 \\
\hline Electric product & -0.010 & 0.005 & -0.015 & 0.079 & -0.005 & 0.084 \\
\hline Transportation equipment & -0.057 & 0.032 & -0.089 & 0.068 & 0.001 & 0.067 \\
\hline Precision products & -0.045 & -0.006 & -0.040 & 0.038 & 0.002 & 0.036 \\
\hline Miscellaneous & -0.071 & -0.005 & -0.066 & 0.033 & 0.035 & -0.002 \\
\hline
\end{tabular}


Table 5. Result of the global and local technical change analysis

\begin{tabular}{|c|c|c|c|c|c|c|c|c|c|}
\hline \multirow{3}{*}{$\begin{array}{c}\text { Number of } \\
\text { enterprises }\end{array}$} & \multirow[b]{2}{*}{ Industry type } & \multicolumn{4}{|c|}{2008 to 2009} & \multicolumn{4}{|c|}{2009 to 2010} \\
\hline & & & GTC & & LTC & & GTC & & LTC \\
\hline & Food and beverage & 4 & $(4.7 \%)$ & 10 & $(11.8 \%)$ & 6 & $(7.1 \%)$ & 18 & $(21.2 \%)$ \\
\hline 37 & Textile & 4 & $(10.8 \%)$ & 7 & (18.9\%) & 8 & (21.6\%) & 4 & $(10.8 \%)$ \\
\hline 15 & Pulp and paper & 1 & $(6.7 \%)$ & 0 & $(0.0 \%)$ & 3 & $(20.0 \%)$ & 4 & $(26.7 \%)$ \\
\hline 159 & Chemical product & 3 & $(1.9 \%)$ & 1 & $(0.6 \%)$ & 9 & $(5.7 \%)$ & 19 & $(11.9 \%)$ \\
\hline 38 & Medical product & 2 & (5.3\%) & 5 & $(13.2 \%)$ & 3 & $(7.9 \%)$ & 19 & $(50.0 \%)$ \\
\hline 9 & Coal and oil & 0 & $(0.0 \%)$ & 0 & $(0.0 \%)$ & 5 & (55.6\%) & 1 & (11.1\%) \\
\hline 16 & Rubber & 1 & $(6.3 \%)$ & 0 & $(0.0 \%)$ & 6 & (37.5\%) & 4 & $(25.0 \%)$ \\
\hline 27 & Nonferrous & 1 & (3.7\%) & 0 & $(0.0 \%)$ & 7 & (25.9\%) & 12 & $(44.4 \%)$ \\
\hline 46 & Iron and steel & 2 & $(4.3 \%)$ & 2 & $(4.3 \%)$ & 10 & (21.7\%) & 13 & (28.3\%) \\
\hline 57 & Metal & 5 & $(8.8 \%)$ & 6 & $(10.5 \%)$ & 11 & (19.3\%) & 10 & $(17.5 \%)$ \\
\hline 48 & Ceramic & 1 & $(2.1 \%)$ & 3 & $(6.3 \%)$ & 9 & $(18.8 \%)$ & 12 & $(25.0 \%)$ \\
\hline 170 & Machine & 2 & $(1.2 \%)$ & 17 & $(10.0 \%)$ & 3 & $(1.8 \%)$ & 9 & $(5.3 \%)$ \\
\hline 181 & Electric product & 4 & $(2.2 \%)$ & 24 & $(13.3 \%)$ & 7 & (3.9\%) & 21 & $(11.6 \%)$ \\
\hline 90 & Transportation equipment & 1 & $(1.1 \%)$ & 17 & $(18.9 \%)$ & 11 & $(12.2 \%)$ & 29 & $(32.2 \%)$ \\
\hline 29 & Precision products & 3 & $(10.3 \%)$ & 5 & $(17.2 \%)$ & 2 & $(6.9 \%)$ & 12 & $(41.4 \%)$ \\
\hline 60 & Miscellaneous & 2 & $(3.3 \%)$ & 2 & $(3.3 \%)$ & 5 & $(8.3 \%)$ & 15 & $(25.0 \%)$ \\
\hline
\end{tabular}

Note: GTC and LTC represent how many firms are observed which achieve GTC and LTC.

Percentage values in parentheses show that share of GTC and LTC observed firms in total number of sample. 
Table 6. Result of the determinants factors of productivity change and innovation

\begin{tabular}{|c|c|c|c|c|c|c|c|c|c|}
\hline \multirow[t]{2}{*}{ Dependent variable name } & \multicolumn{2}{|c|}{$\mathrm{TFP}_{\mathrm{CP}}$} & & \multicolumn{2}{|c|}{ GTC } & & \multicolumn{2}{|c|}{ LTC } & \\
\hline & Coef. & $\begin{array}{c}\mathrm{z}- \\
\text { value }\end{array}$ & & $\begin{array}{c}\text { Coef } \\
.\end{array}$ & $\begin{array}{c}\mathrm{z}- \\
\text { value }\end{array}$ & & $\begin{array}{c}\text { Coef } \\
.\end{array}$ & $\begin{array}{c}\mathrm{z}- \\
\text { value }\end{array}$ & \\
\hline Protection by patent & 0.002 & 0.420 & & 0.08 & 0.21 & & 0.14 & -0.51 & \\
\hline Protection by design patent and trademark & 0.005 & 0.740 & & 0.54 & 1.36 & & 0.16 & 0.56 & \\
\hline protection by trade secret & 0.003 & -0.540 & & 0.21 & 0.53 & & 0.31 & -1.02 & \\
\hline Complication of product architecture and service design & 0.007 & 1.170 & & 0.20 & 0.52 & & 0.13 & -0.48 & \\
\hline Making the "Black Box" (technology and/or process) & 0.009 & 1.730 & $*$ & 0.13 & 0.33 & & 0.30 & 1.11 & \\
\hline $\begin{array}{l}\text { Differentiation by external design and sensibility } \\
\text { element }\end{array}$ & 0.006 & -1.480 & & 0.23 & 0.75 & & 0.02 & -0.09 & \\
\hline Improvement of convenience by product interface & 0.006 & 1.110 & & 0.38 & -0.86 & & 0.15 & -0.50 & \\
\hline Protection and management of production know-how & 0.002 & 0.260 & & 1.00 & 2.08 & $* *$ & 0.24 & 0.73 & \\
\hline $\begin{array}{l}\text { Internal production of manufacturing device and } \\
\text { equipment }\end{array}$ & 0.006 & 1.220 & & 0.44 & -1.29 & & 0.12 & -0.48 & \\
\hline Cost advantages by achievement of scale merit & 0.009 & -1.960 & $\begin{array}{l}* \\
*\end{array}$ & 0.35 & 0.99 & & 0.28 & 1.14 & \\
\hline $\begin{array}{l}\text { Cost reduction by early entry into market to create } \\
\text { know-how }\end{array}$ & 0.004 & -0.520 & & 0.22 & -0.53 & & 0.23 & -0.70 & \\
\hline $\begin{array}{l}\text { Acquisition of market share by early product/service } \\
\text { launch }\end{array}$ & 0.004 & 0.530 & & 0.37 & 0.85 & & 0.35 & 1.01 & \\
\hline Relationship with customer by early commercialization & 0.003 & -0.400 & & 0.57 & -1.25 & & 0.94 & -2.55 & $* *$ \\
\hline Development of optional goods and customer services & 0.004 & -0.820 & & 0.30 & 0.83 & & 0.21 & 0.82 & \\
\hline Standardization of product/service & 0.001 & 0.140 & & 0.14 & 0.35 & & 0.96 & 2.78 & $\begin{array}{l}* * \\
*\end{array}$ \\
\hline $\begin{array}{l}\text { Establishment and use of brand (corporate, product, } \\
\text { service) }\end{array}$ & 0.010 & -1.620 & & 0.48 & 1.14 & & 0.19 & -0.62 & \\
\hline $\begin{array}{l}\text { Construction of flexible productive system for demand } \\
\text { change }\end{array}$ & 0.012 & -1.860 & $*$ & $1.38^{-}$ & -2.92 & $\begin{array}{l}* * \\
*\end{array}$ & 0.07 & 0.23 & \\
\hline Maintenance of network for sales and service & 0.005 & 0.750 & & $0.2{ }^{-}$ & -0.58 & & 0.09 & -0.31 & \\
\hline Constant & 0.014 & 0.420 & & $\begin{array}{r}- \\
6.74 \\
\end{array}$ & -2.71 & $\begin{array}{l}* * \\
* \\
\end{array}$ & $\begin{array}{r}- \\
2.96 \\
\end{array}$ & -1.75 & $*$ \\
\hline \# of sample & & 343 & & & 343 & & & 343 & \\
\hline R-square: within / Log likelihood & & 0.0548 & & & -52.70 & & & -132.05 & \\
\hline R-square: between / Wald chi2(18) & & 0.0542 & & & 17.61 & & & 13.61 & \\
\hline R-square: overall / Prob > chi2 & & 0.0473 & & & 0.48 & & & 0.75 & \\
\hline
\end{tabular}

Note1: * **, and *** indicate statistical significance at the $10 \%, 5 \%$, and $1 \%$ levels, respectively.

Note2: The result which uses $\mathrm{TFP}_{\mathrm{CP}}$ as dependent variables is calculated by Random-effects generalized least squares (GLS) regression and observed R-square. The results which use GTC and LTC as dependent variables are calculated by Random-effect logistic regression and observed log likelihood and Wald chi2 score. 


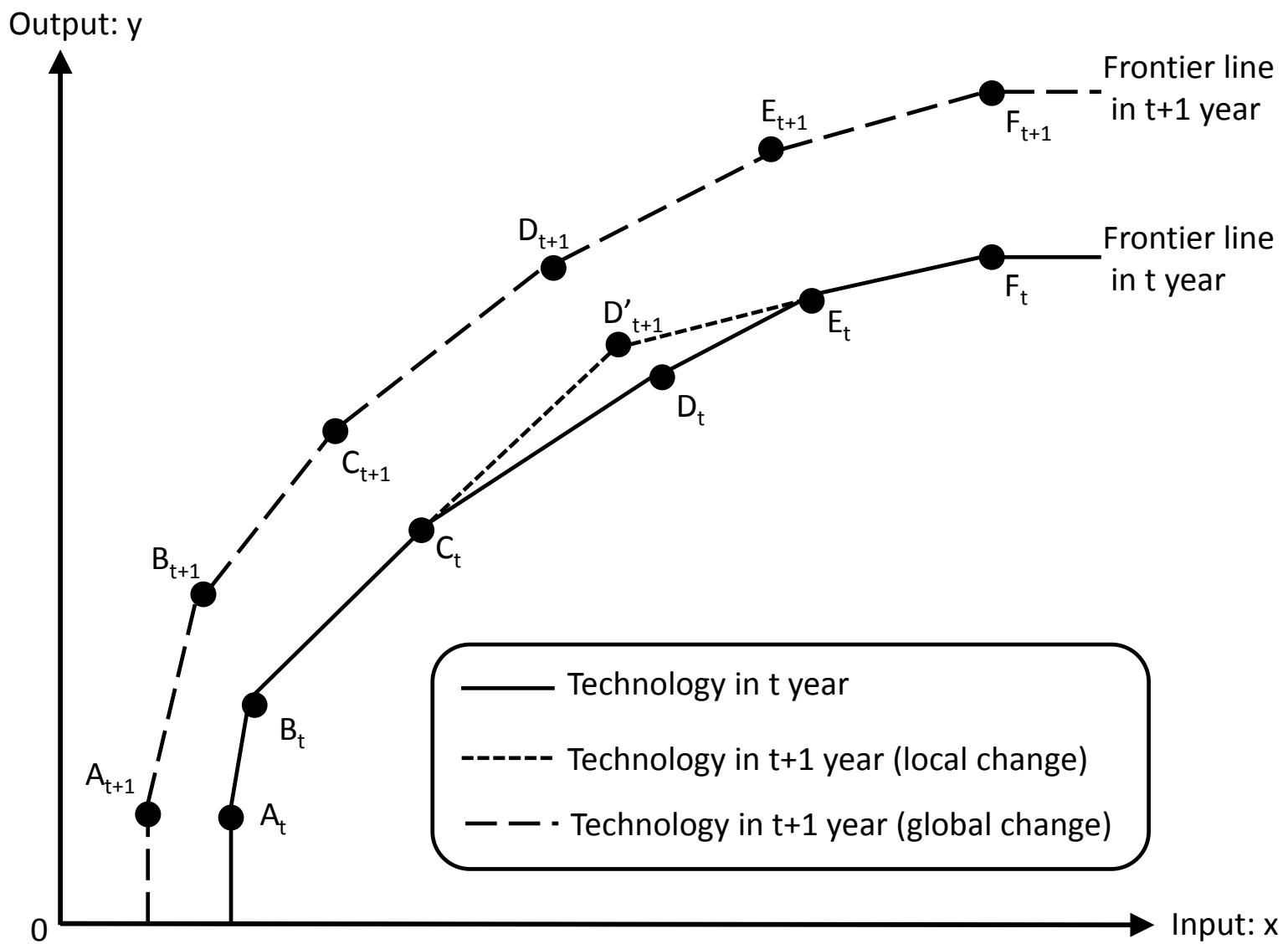

Figure 1. Global technical change and local technical change. 


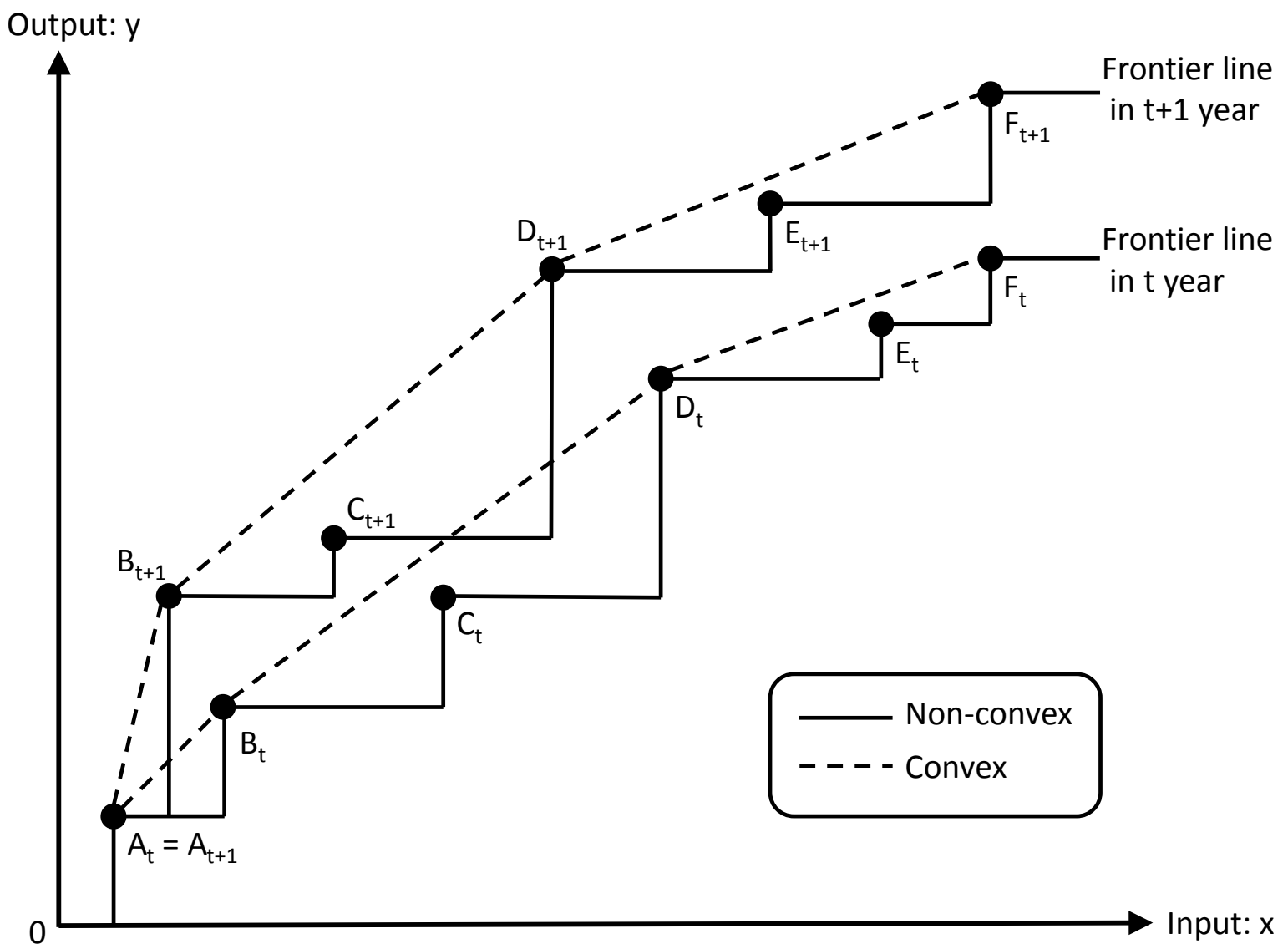

Figure 2. Production frontier line under non-convex and convex technologies. 


\section{Appendix}

The "Survey on Research Activities of Private Corporations Report 2011" had responding and nonresponding firm (response rate is $37.4 \%$ ). The means of performances (sales per capita, profit per capita, and $R \& D$ expenditure per capita) between them are the following.

Table A1. differences in the performances

\begin{tabular}{lcc}
\hline & Sales per capita & R\&D per capita \\
\hline \multirow{2}{*}{ Responding firms } & 105.24 & 1753.74 \\
& $(33.51)$ & $(101.56)$ \\
\hline \multirow{2}{*}{ Non-responding firms } & 74.07 & 1769.61 \\
& $(20.07)$ & $(112.29)$ \\
\hline \multirow{2}{*}{ Difference } & -31.17 & 15.87 \\
& $(36.68)$ & $(166.53)$ \\
\hline
\end{tabular}

